\title{
日高山脈トッタベッ谷における氷河底変形地層について
}

\author{
岩 崎 正 吾* 澤 柿 教 伸** 平 川一臣**
}

\section{Subglacial Deforming Bed in the Tottabetsu Valley, the Hidaka Mountain Range}

Shogo IWASAKI *, Takanobu SAWAGAKI ** and Kazuomi HIRAKAWA **

\begin{abstract}
In recent years, the "subglacial deforming bed" has attracted attention as a factor of glacier dynamics. Subglacial deforming beds, named T8-till and T9-till respectively in this study, were formed at two locations in the Hidaka Mountain Range during the glacier's maximum advance (Poroshiri Stade) of the Last Glacial Stage. These subglacial deforming beds are characterized by deformation structures such as shear planes, folds and fault gouge formed under compaction in the vertical direction and drag in the horizontal direction. T8-till and T9till had been deformed by two cycles and one cycle of glacial advance and retreat, respectively. Strain at these subglacial deforming beds reconstructed using shear angle and degree of fracturing indicate that T8-till developed beneath the first warm-based and the second coldbased glaciers, while T9-till was beneath the cold-based glacier.
\end{abstract}

Key words: subglacial deforming bed, subglacial bed deformation, Glaciation, Poroshiri Stade, Hidaka Mountain Range

キーワード : 水河底変形地層, 氷河底地層変形, 氷河作用, ポロシリ亜氷期, 日高山脈

\section{I.はじめに}

1986 年に, 西南極水床アイスストリームの流速 の大部分は, 氷河の下の地層の変形 “subglacialbed deformation (以下, 水河底地層変形)”によっ て生じている可能性が示された (Alley et al., 1986; Blankenship et al., 1986)。これを契機と して, 水河底地層変形の問題は氷河作用研究にお ける重要な課題の一つとなってきた。それまでの 研究では, “ice deformation (以下, 水の変形)” と “basal sliding (以下, 底面すべり)” が水河の
流動を規定する要因と考えられていたが, “水河底 地層変形”もまた氷河流動ダイナミクスを決定づ ける要因として新たに認識されるようになったの である。Boulton（1986）はこの認識の変革を 「氷河学におけるパラダイムシフト」と呼んだ。

氷河底地層変形に関する研究では, 現存水河に おける直接的な観察は容易でない。そこで, 氷河 消滅地域に残されている, 氷河底で変形プロセス を被った地層起源の堆積物 “subglacial deforming bed (以下, 水河底変形地層)” が重要な研究 対象となっている。とくに, 北米・北欧に発達し

\footnotetext{
*日本学術振興会特別研究員 (北海道大学大学院地球環境科学研究科)

$* *$ 北海道大学大学院地球環境科学研究科

* JSPS Research Fellow, Graduate School of Envitonmental Earth Science, Hokaiido University

** Graduate School of Environmental Earth Science, Hokkaido University
} 
た更新世水床によるこのような堆積物について， 多くの研究が行われている。しかし，氷期の日高 山脈に発達したような全長 $4 \mathrm{~km}$ 程度の小規模山 岳水河の水河底変形地層に関する研究は非常に少 なく，世界的に見てもBenn（1994）の例がある だけである。筆者らは，日高山脈中央部トッタべ ツ谷において氷河底変形地層を見いだしており (岩崎ほか, 2000a), その堆積物に注目すること は日高山脈の更新世水河のみならず小規模山岳水 河の水河底環境を解明する上でも重要である。本 稿では, 日高山脈中央部トッタベッ谷の 2 地点で 発見した最終水期ポロシリ亜氷期（小野・平川， 1975; 岩崎ほか, 2000a, b) の水河底変形地層（そ れぞれ“T8-till”, “T9-till”と呼ぶ）を肉眼スケー ルで詳細に記載し（縮尺 1/10のスケッチ作成）, それに基づいて氷河地質学的・氷河学的意義を検 討する。

\section{II. 水河底変形地層の定義と基本概念}

従来の研究において, 氷河の消滅後に残された 水河底堆積物は, “lodgement till” “subglacial melt-out till” “deformation till”(例えば, Dreimanis, 1989; Benn and Evans, 1998; Boulton et al., 1996) などと呼ばれ分類されてきた。これ らは, 主として氷河底での初成的堆積プロセスを 分類基準とする用語である。いっぽう，Ruszczynska-Szenajch (2001) は, 氷河底の初成的堆 積プロセスと水河性テクトニクスを組み合わせた 基準にしたがって, “hard lodgement till” “soft lodgement till” “glaciotectonic diamicton”など を定義している。また, 前章で述べたように, 現 在の水河・氷床下にある地層での変形プロセスが ひろく認知されるに伴い, 初成的堆積プロセスゃ 水河性テクトニクスの種類にかかわらず, 水河底 で変形された堆積物を総称する用語として “deformable bed till” (Hart, 1995, 1998) が提 唱された。しかし，この用語はまだひろく受け入 れられているとはいえない。また, 初成的堆積プ ロセスや水河性テクトニクスに基づく水河底堆積 物の分類・定義は, 現在においても議論の途上に あるといってよいだろう。そこで本稿では，かつ
て氷河が流動していた時期に氷河底で変形プロセ スを被り，現在地層として残存している堆積物を， 総称して “氷河底変形地層”と呼ぶ。

図 1A は Hart and Boulton（1991）が示した 水河底変形地層の形成に関わる堆積・侵食・運搬・ 変形プロセスの概念図である。これによると, 水 河底変形地層は前進しつつある氷河の下で, “shearing-in” “folding-in” “lodgement”そして “melt-out”の四つのプロセスによって物質を内部 に取り込みながら形成される。水河底変形地層は, これらのプロセスによって取り込まれる物質の質 や量, 取り込まれた後の変形の程度などの違いを 反映して多様な層相を示すが, 模式的には図 $1 \mathrm{~B}$ の様に表される。この図からわかるように，氷河 底変形地層は剪断面や褶曲などの構造で特徴づけ られ，それらが氷河底変形地層の認定基準となる。 氷河底地層の変形の様式および度合いは, その 剪断強度と摩擦強度，およびそれに働く水河性剪 断応力のバランスによって決まる。例えば，剪断 応力が剪断強度よりも小さく, 摩擦強度よりも小 さい場合には, 水河底面に近い氷河底地層最上部 に限って歪が生じる。また, 剪断応力が剪断強度 と摩擦強度よりも小さい場合には水河底地層に変 形が起こらず，反対に大きい場合には，剪断応力 と剪断強度が釣合う深さまで地層の変形が起こる。 後者の場合の典型的な層相が図 1Bである。

\section{T8-till の記載}

\section{1）露頭の地形的位置と概観}

T8-till が観察される地点 T8 は,トッタベツ谷底 部（本流の現河床標高 $935 \mathrm{~m}$ ）の右岸に位置して いる（図 2, 口絵 1-1）。ここでは，現河床上 $42 \mathrm{~m}$ に段丘状の地形表面があり，その直下の層準（現 河床上 25-40 m) に好露頭がある（図 3 左，口絵 1-2)。ここで見られる堆積物は, 上位から順に層 相の異なる $\mathrm{A} \cdot \mathrm{B} \cdot \mathrm{C} \cdot \mathrm{D}$ の四つのユニットからな る（図 4）。ユニット $\mathrm{A}$ と B および B と C の境界 は共に明瞭であり，いっぽうユニット C と D の境 界は不明瞭である。このうち本稿で T8-till とした のは，ユニット $\mathrm{A} \cdot \mathrm{B} \cdot \mathrm{C}$ である。 


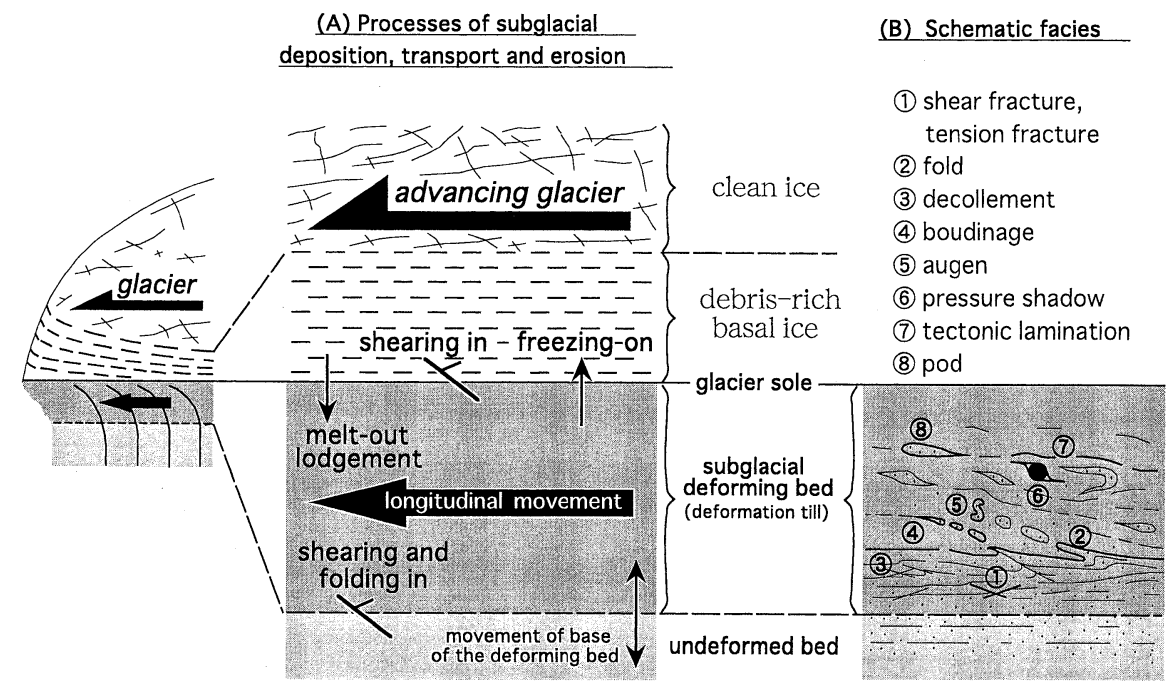

図 1 水河底変形地層の基本概念.

A : Hart（1998）を改訂. B : Hart and Boulton (1991), Dreimanis (1993), Hart (1998) を編集.

Fig. 1 Basic concept of subglacial deforming bed.

A : modified from Hart (1998). B : compiled from Hart and Boulton (1991), Dreimanis (1993) and Hart (1998).

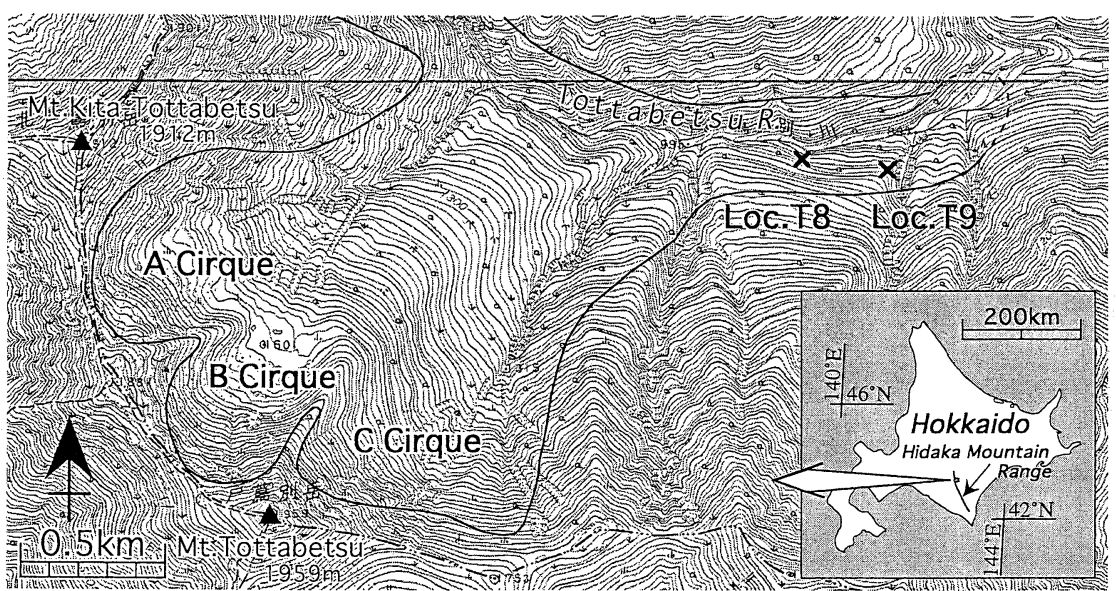

図 2 露頭の位置と最終水期水河最大拡大期（ポロシリ亜水期）の水河の範囲. 基図は国土地理院発行 1/25,000 地形図「ピパイロ岳」と「幌尻岳」.

Fig. 2 Locations of outcrops and the extent of the maximized glacier during the Poroshiri Stade of the Last Glacial Stage.

Base maps are 1/25,000 topographical maps "Pipairodake" and "Poroshiridake" by the Geographical Survey Institute of Japan. 

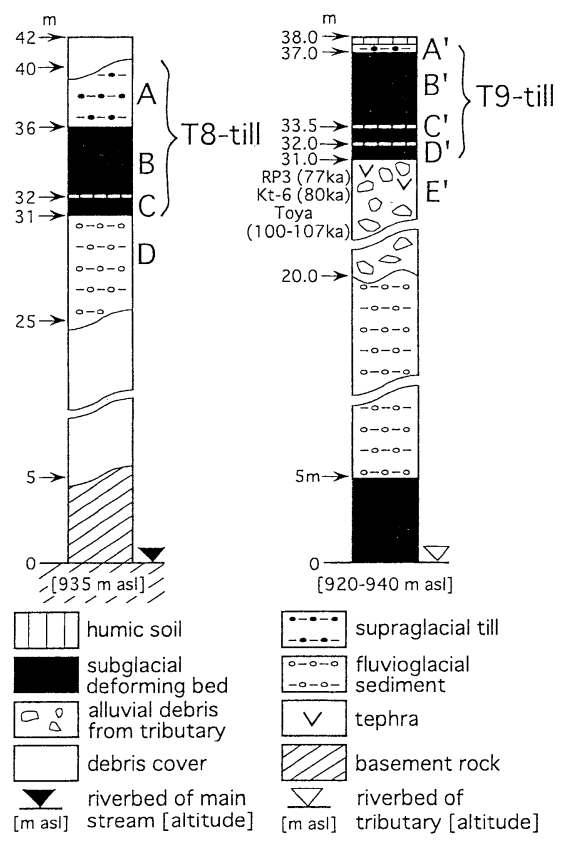

図 3 地点 $\mathrm{T} 8$ （左）と $\mathrm{T} 9$ （右）の堆積物柱状図.

Fig. 3 Columnar sections at locations T8 and T9.

\section{2）層相と堆積構造}

ユニット A（現河床上 $36 \mathrm{~m}$ 以上の層準）：厚さ $4 \mathrm{~m}$ 以上のルーズな角礫層。直径数センチメート ルから $4 \mathrm{~m}$ までの角閃岩礫だけで構成されている。 ユニット B (現河床上 $32-36 \mathrm{~m}$ の層準)：厚さ 約 $4 \mathrm{~m}$ の緻密な礫支持礫層。角閃岩の角礫だけか らなり，風化した基盤岩のような層相を呈すると ころが多く, 非常に緻密である。このユニットを 構成する角礫は, 密に発達した破断面によって直 径数センチメートルから $50 \mathrm{~cm}$ 程の大きさに破砕 されている。破断面には, 見かけ上, 図 4 の左下 方向に選択的に配列する連続性のよいものがある （図 4 の構造(1), 口絵 1-3)。三次元方位解析に基 づくそれらの最大傾斜方位と傾斜角の平均は, そ れぞれ $81.9^{\circ}$ および $39.7^{\circ}$ である（図 5)。また， このユニットの基底近くには石英と長石の脈（図 4, 口絵 1-3）があり, 多数の破断面によって切ら れているものの, $1 \mathrm{~m}$ 以上にわたってほぼ連続し ている。このような破断された石英・長石の脈は ユニット Bの数力所で見られる。
ユニット C (現河床上 31-32 $\mathrm{m}$ の層準)：層厚 約 $1 \mathrm{~m}$ 。主として粘土サイズの細粒物質で構成さ れる基質支持ダイアミクトン。本ユニットには, 角閃岩やダナイトなど多様な岩質の円〜亜円磼が 含まれ，図 4 の左下方向への選択配向性を持つ無 数の破断面（図 4 の構造(5) が特徽的に発達して いる。また最上部には，本ユニットがユニット B に取り込まれるように生じている褶曲（図 4 の構 造(2)，口絵 1-4）が見られる。ユニット B/C 境界 直下には, 境界面に沿ってほぼ水平方向に連続す る角閃岩角碟と石英・長石の破砕岩片を挟む破断 面（図 4 の構造(3), 口絵 1-5) がある。また， ユ ニット C と D の境界は漸移的だが, その付近の層 準にはオレンジ色に風化・変色したダナイト碩の 破砕岩片（直径 $10 \mathrm{~cm}$ 以下）が, ほほ水平方向に 並んでいる（図 4 の構造(4), 口絵 1-6)。

ユニット D（現河床上 $31 \mathrm{~m}$ 以下の層準）: 厚さ $6 \mathrm{~m}$ 以上のシルト質砂の基質支持河成砂層。この ユニットは, 角閃岩やダナイトなどの円〜亜円礫 からなる。また, 水流の作用で形成されたことを 示す粗粒な砂のレンズや, シルトのラミナが観察 され, 河成一融氷河流成の堆積物と考えられる。

\section{T9-till の記載}

\section{1）露頭の地形的位置と概観}

T9-tillの露出する地点 T9 は, トッタベッ川本流 の標高 $897 \mathrm{~m}$ 付近で右岸から合流する支流の左 岸に位置する（図 2)。露頭全体の幅は約 $80 \mathrm{~m}$, 高さは約 $40 \mathrm{~m}$ である。本研究では, ティルの露 出が最もよい露頭の左側上部において幅・高さ共 に約 $10 \mathrm{~m}$ の範囲で記載を行い, 層相の違いから堆 積物を上位から順に $\mathrm{A}^{\prime}, \mathrm{B}^{\prime}, \mathrm{C}^{\prime}, \mathrm{D}^{\prime}, \mathrm{E}^{\prime}$ の五つに 区分した（図3右, 図6, 口絵 1-7)。ユニット $\mathrm{A}^{\prime} \cdot \mathrm{B}^{\prime} \cdot \mathrm{C}^{\prime} \cdot \mathrm{D}^{\prime}$ の各境界はいずれも明瞭であるが, ユニット $\mathrm{D}^{\prime}$ と $\mathrm{E}^{\prime}$ の境界は不明暸である。

\section{2）層相と堆積構造}

ユニット $\mathrm{A}^{\prime}$ (現河床上 37.0-37.5 m の層準 ; 堆 積頂面直下の層準): 厚さ約 $50 \mathrm{~cm}$ のオープンワー クの礫層で, 直径 $10-30 \mathrm{~cm}$ の角閃岩角鿬だけか らなる。

ユニット $\mathrm{B}^{\prime}$ （現河床上 $33.5-37.0 \mathrm{~m}$ の層準）： 


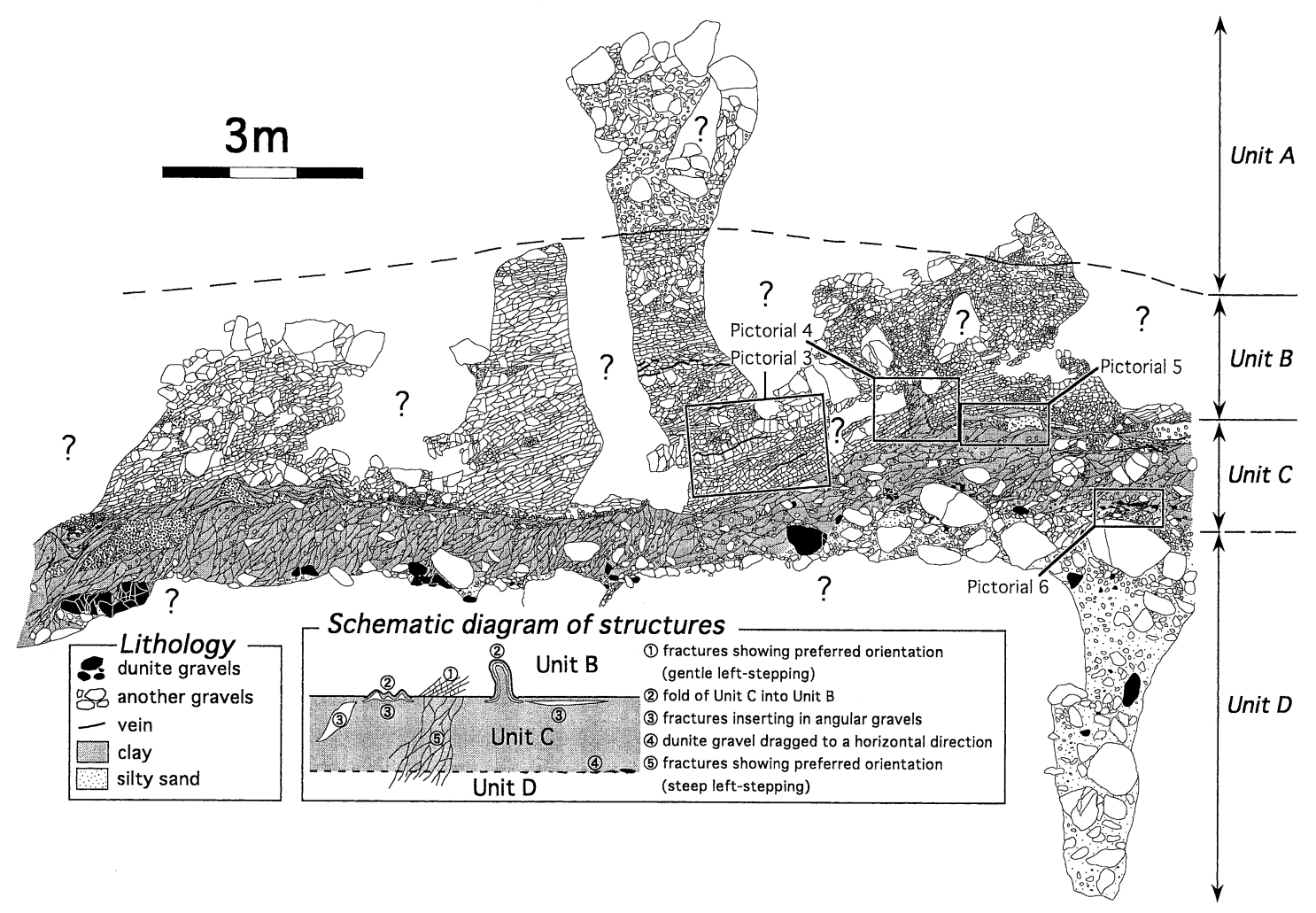

図 4 T8-till の層相.

Fig. 4 Facies of T8-till.

見かけの厚さ 0.5-2 $\mathrm{m}$ の緻密な礫支持礫層。この ユニットは, 無数の破断面を伴う角閃岩砂だけか らなり, 風化した基盤岩のような層相を示す。破 断された礫の長径は, 基底付近では $5 \mathrm{~cm}$ 前後であ るが，上位ほど粗粒化し（図 6, 口絵 1-8）, 最上 部では $20-30 \mathrm{~cm}$ 前後となる。破断面は, 見かけ 上，露頭の右下方向あるいは左下方向に配列する 傾向がある（図 6 の構造(1)', 口絵 1-9)。三次元 方位解析の結果, 破断面の最大傾斜方位と傾斜角 は，それぞれ平均 $97.7^{\circ} ， 37.8^{\circ}$ が得られた（図 5)。 また破断面の一部には, 粘土サイズの物質が見ら れ（図 6 の構造(2)'，口絵 1-10), 破断面に沿うラ ミナが顕著に発達している（口絵 1-11）。

ユニット C'（現河床上 $32.0-33.5 \mathrm{~m}$ の層準）： 角閃岩の角碟だけで構成される緻密な礫支持磁層。 見かけ上の層厚は 0.5-2.0 m で, 露頭の左側ほど
厚くなる傾向がある。ユニット $\mathrm{B}^{\prime}$ よりも密に破断 面が発達しており（図6 の構造(3)', 口絵 1-12), 構成礫径は 2-10 mm と細粒化する。また破断面 は，上下のユニット境界とほぼ平行で連続性がよ い。このユニットには, ユニット B' 中に認められ る粘土サイズの物質を挟む破断面がスムーズに連 続する（図 6)。

ユニット $\mathrm{D}^{\prime}$ ・ $\mathrm{E}^{\prime}$ （現河床上 31-32 m と 20-31 $\mathrm{m})$ : 共に砂質シルトの基質支持礫層。両ユニット とも, 直径数センチメートルから $1 \mathrm{~m}$ 程度の角閃 岩角磁を多数含む。しかし，ユニット D'にだけ破 断面が認められることから（図 6 の構造(4)'), ユ ニット D'と $\mathrm{E}^{\prime}$ を区別した。ユニット $\mathrm{E}^{\prime} に は$ 直径 $2 \mathrm{~m}$ 前後の角閃岩の巨角啋密集層があり, 支流の 上流（露頭の左）から本流（露頭の右）方向へ約 $10^{\circ}$ で傾斜している（口絵 1-7）。 


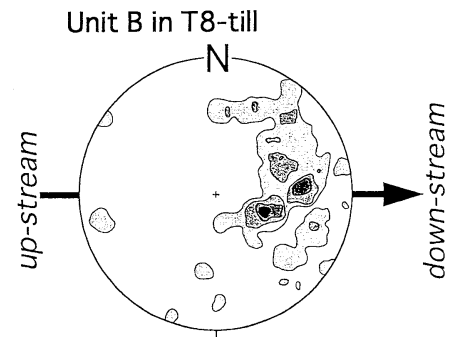

A: $81.9^{\circ}, P: 39.7^{\circ}, n: 100$

Unit B' in T9-till

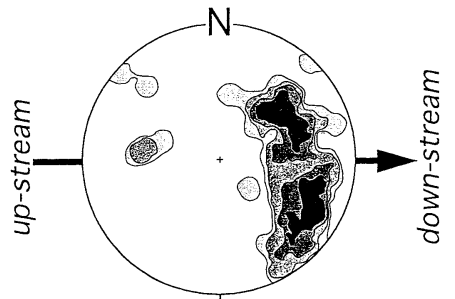

$\mathrm{A}: 97.7^{\circ}, \mathrm{P}: 37.8^{\circ}, \mathrm{n}: 100$

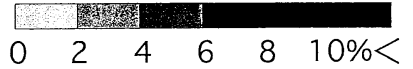

図 5 ユニット B とユニット $\mathrm{B}^{\prime}$ 中の破断面（リー デル剪断面）の姿勢.

破断面（リーデル剪断面）の最大傾斜方位と その角度をシュミットネットの下半球に投影 した. $\mathrm{A}$ ：平均方位; $\mathrm{P}$ : 平均傾斜角 $; \mathrm{n}$ : 測 定した破断面（リーデル剪断面）の数.

Fig. 5 Attitudes of fractures (Riedel shears) in Units B and B' projected on Schmidt's net. Equal-area, lower hemisphere projection of poles of maximum dip directions and angles of fractures (Riedel shears). A : Azimuth ; P : Dip ; n: number of flactures (Riedel shears).

\section{V. 解釈と議論}

\section{1）ティルの認定}

(1) T8-till

T8-till は, $\mathrm{A} ・ \mathrm{~B} \cdot \mathrm{C} \cdot \mathrm{D}$ の四つのユニットから なり,このうちユニット $\mathrm{B} \cdot \mathrm{C}$ に特徵ある変形構 造が発達している。とくに，ユニット Cの最上位 に発達する褶曲（図 4 の構造(2), 口絵 1-4) と角 閃岩角礫と石英・長石の破砕岩片を挟む破断面（図 4 の構造(3), 口絵 1-5）は明らかな変形構造であり, 褶曲は水平方向への短縮, 破断面は引きずりに よって形成されたと理解できる。また，ユニット
$\mathrm{C}$ の褶曲がユニット B の最下部に貫入しているこ とは，ユニット B が水平方向への短縮を受けたこ とを示す。さらに，基質をほとんど伴わない緻密

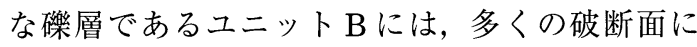
よって切られた石英脈が最大 $1 \mathrm{~m}$ にわたって連続 する（口絵 1-3）。この事実は，ユニット Bがもと もと直径 $1 \mathrm{~m}$ 大の礫を含むオープンワークの粗粒 礫層であったことを示すとともに，ユニット B が 水平方向への短縮だけでなく垂直方向への圧密を 受けたことを意味する。

以上のような構造の存在から，ユニット $\mathrm{B} ・ \mathrm{C}$ は垂直応力と剪断応力を受けた脆性剪断帯である といえる。その剪断方向と成因については, ユニッ ト B の選択配向性を持つ破断面（図 4 の構造(1) に基づいて検討できる。一般に脆性剪断帯には, $\mathrm{R} 1$ 面, R2 面, $\mathrm{P}$ 面, $\mathrm{Y}$ 面と呼ばれる剪断面が発 達し, それらの姿勢は剪断方向を反映して選択的 に配列することが知られている（狩野・村田, 1998)。なかでも，R1 面はリーデル剪断面とも呼 ばれ, 剪断带の中で最も連続よく発達し, その最 大傾斜方位は剪断方向の下流側に斜行するとされ ている。したがって，ユニット B に見られる選択 配向性を持つ破断面はリーデル剪断面と考えられ る。また，その最大傾斜方位の平均は東方向（図 5), すなわちトッタベッ川の流下方向であり, こ れは, 想定される氷河の流動に伴う剪断方向と一 致する。さらに, ユニット Bに㗢いた圧密は, 氷 河の自加重圧（垂直応力）で説明できる。

以上のことから, ユニット $\mathrm{B} \cdot \mathrm{C}$ を氷河底で引 きずられて変形した氷河底変形地層であると判断

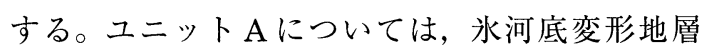
（ユニット B）を直接覆うことから, 氷河の内部㧍 よび表面にあった岩屑を起源とする氷河上ティル とともに付近の谷壁からの崖錐性堆積物も含まれ ると思われる。ユニット D は河成砂礫層の層相を 呈し, 水河底変形地層 (ユニット C) に直接覆わ れることから, 水河の前進に伴って氷河前方に堆 積した融水河流堆積物であると解釈した。

(2) T9-till

層相から五つのユニットに区分された地点 T9 の堆積物には，三つのユニット $\left(\mathrm{B}^{\prime} \cdot \mathrm{C}^{\prime} \cdot \mathrm{D}^{\prime}\right)$ に 


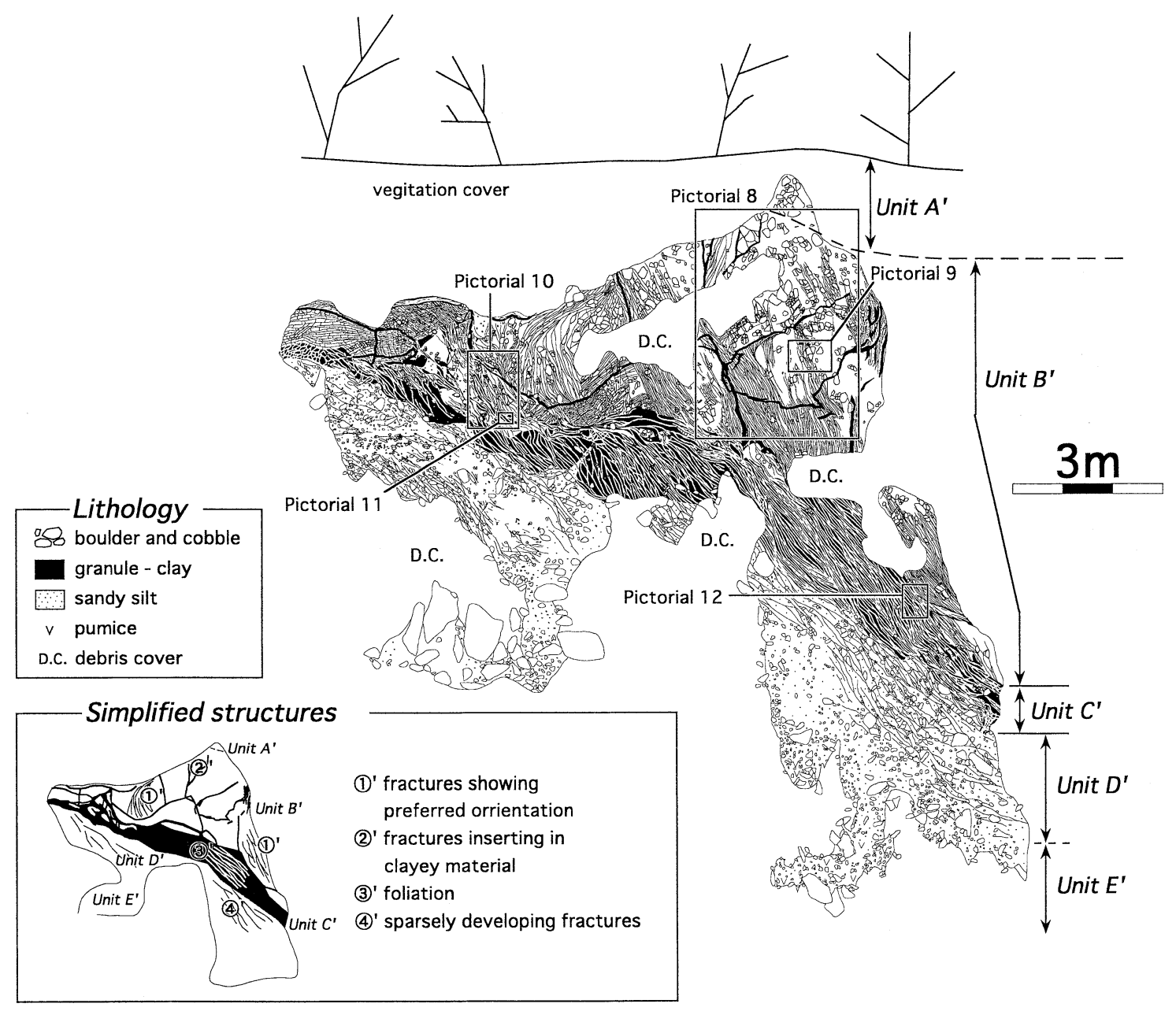

図 6 T9-till の層相.

Fig. 6 Facies of T9-till.

特徵的な堆積構造が発達する。なかでも, 粘土サ イズの物質を挟む破断面（図 6 の構造(2)', 口絵 110・11）は, 脆性剪断帯によく見られる変形構造 である。すなわち，その破断面は剪断面であり， そこに歪が集中することによってテクトニックラ ミネーションを伴う断層粘土状物質が形成された と解釈できる。このことから，ユニット $\mathrm{B}^{\prime}$ および その下位のユニット $\mathrm{C}^{\prime} \cdot \mathrm{D}^{\prime}$ に見られる破断面（図 6 の構造(1)'，(2)'，(3)') も剪断面と解釈できる。

以上の構造の存在から, ユニット $\mathrm{B}^{\prime} \cdot \mathrm{C}^{\prime} \cdot \mathrm{D}^{\prime}$ は 剪断帯と考えられる。これらのユニットは堆積面
直下で形成されており，氷河以外ではその成因を 説明できない。また，ユニット $\mathrm{B}^{\prime}$ の選択配向性を 持つ破断面（図6の構造(1)') はリーデル剪断面と 解釈され，その最大傾斜方位（図 5) に基づくと, ユニット $\mathrm{B}^{\prime} \cdot \mathrm{C}^{\prime} \cdot \mathrm{D}^{\prime}$ を形成した剪断作用は東方向 すなわちトッタベッ川の流下方向に働いた。した がって, ユニット $\mathrm{B}^{\prime} \cdot \mathrm{C}^{\prime} \cdot \mathrm{D}^{\prime}$ を氷河底変形地層と 判断した。その直上に載る破断を受けていないユ ニット $\mathrm{A}^{\prime}$ は, 層序関係から水河上ティルと解釈す る。また,ユニット $\mathrm{E}^{\prime}$ には, 支流の上流側からトッ タベッ本流に向けて傾斜する層理（口絵 1-7）が 


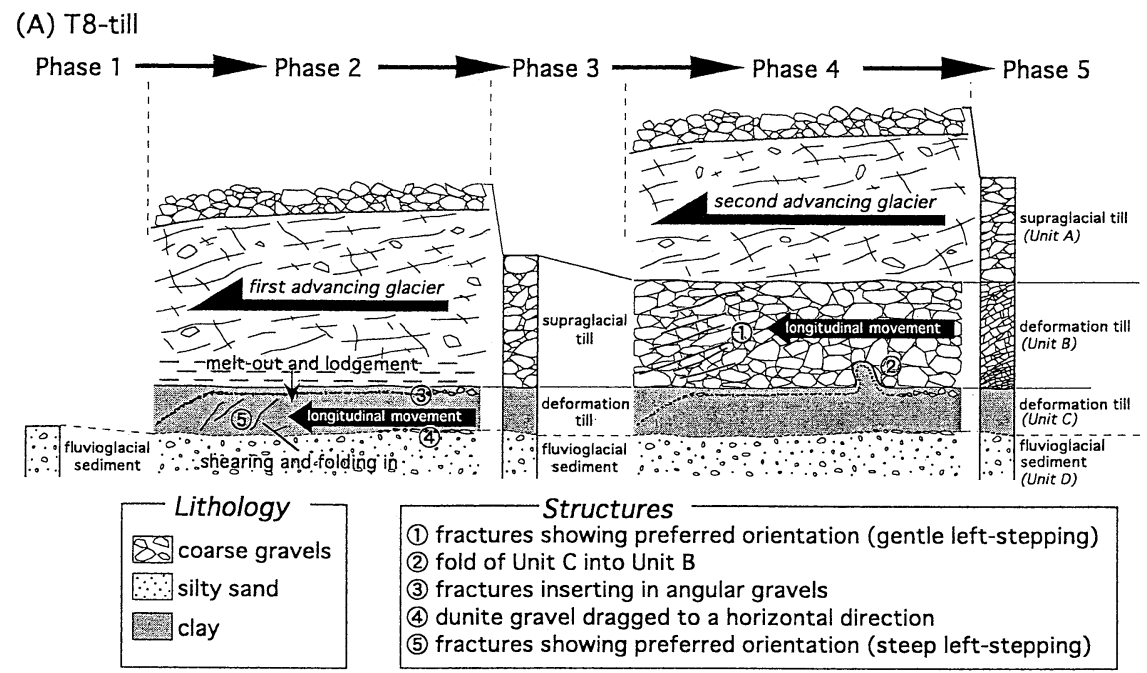

(B) T9-till
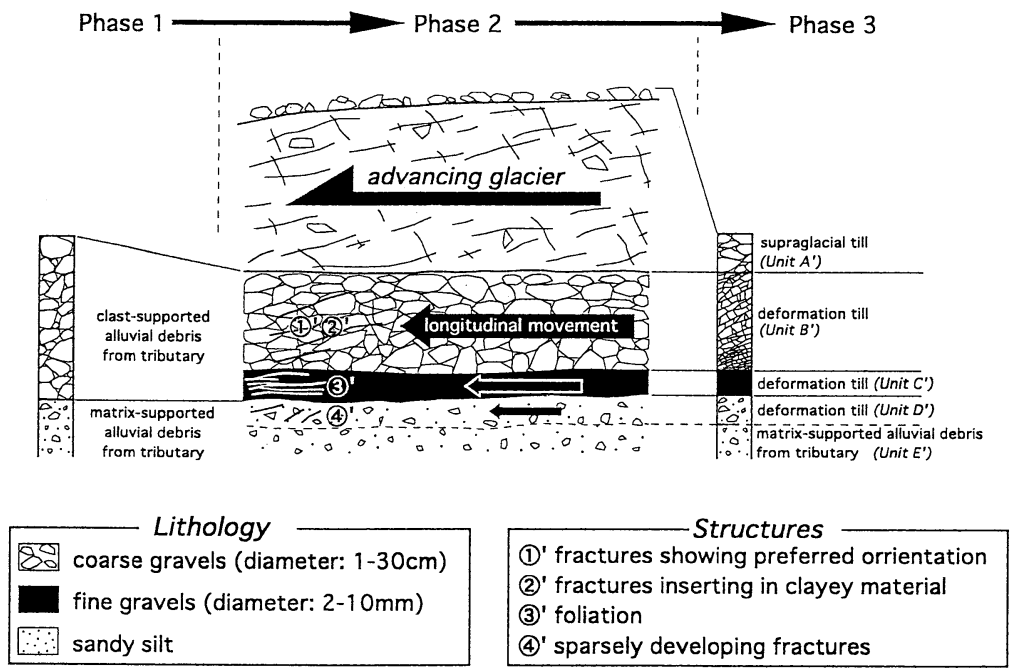

図 7 T8-till と T9-till の形成過程.

Fig. 7 Schematic diagrams showing formative processes of $\mathrm{T} 8$-till and T9-till.

見られ, 水河が地点 $\mathrm{T} 9$ に達する以前に形成されて いた支流性堆積物である。

\section{2) ティルの形成過程}

(1) T8-till

T8-till の水河底変形地層は二つのユニット $\mathrm{B} \cdot \mathrm{C}$-に区分された。これらの二つのユニットを 別々の水河前進に伴ってに生じたものと判断し,

T8-till の発達について, 以下の五つのフェーズか らなる形成過程を復元した（図 7A)。
Phase 1 ：氷河に覆われる前の地点 $\mathrm{T} 8$ にはユ ニット Dによって示される融水河流堆積物が 堆積していた。

Phase 2 : 融水河流堆積物の上に氷河が前進し, すでにあった outwash flood-loam（fluvioglacial sediment）を変形し，さらに底面水 からもロジメントやメルトアウトプロセス等 による粘土サイズ物質の供給によって，ユ ニット C が生じた。その際，ユニット Cには 
「選択配向性を持つ破断面」と「角礫を挟む破 断面」, ユニット $\mathrm{C} / \mathrm{D}$ 境界には「水平方向へ 引きずられたダナイトの破砕礫」が形成され た。

Phase $3:$ その後の水河の縮小過程において, 水河表面や氷河の中にあった粗粒な角閃岩磁 がユニット Cの上に堆積した。氷河後退後に 崖錐性の角閃岩砂がつけ加わっている可能性 が大きい。

Phase 4 : 角閃岩磁層はもともとオープンワー クであったが，再び前進してきた氷河によっ て圧密され，かつ水平方向に短縮された。そ れがユニット Bであり，この時にユニット B の「選択配向性を持つ破断面」と，ユニット $\mathrm{B} / \mathrm{C}$ 境界の「褶曲」が形成された。

Phase 5: 最後に, 水河の縮小過程において, 氷河表面や氷河中起源の磁が堆積し, ユニッ トAが形成された。

剪断帯は粗粒な物質が細粒になっていくことで 形成される。仮にこれら水河底変形地層が一連の 剪断作用で形成されたとすれば，より細粒な物質 で構成されるユニット C はユニット B とユニット $\mathrm{D}$ (融水河流堆積物) の構成物質を取り込んで発 達したことになる。

このことを如実に示しているのが，ユニット C/D 境界の漸移帯に見られる水平方向に並んだダ ナイト礫の破砕岩片（図 4 の構造(4), 口絵 1-6) である。水平方向に並んだダナイト磁片は, ユニッ ト C がユニット D（融水河流堆積物）の構成物質 を取り込む過程の構造と理解できる。さらに，ユ ニット $\mathrm{C}$ 最上部（ユニット $\mathrm{B} / \mathrm{C}$ 境界）に沿って， 角閃岩の角碟と石英・長石の破砕岩片を挟む破断 面（図 4 の構造(3)，口絵 1-5）が発達している。 また，そこに挟まれる角閃岩はユニット B を構成 する岩質と同じである。これらのことから,ユニッ ト $\mathrm{C}$ 最上部の破断面はユニット C がユニット $\mathrm{B}$ の 構成物質を取り込んだ構造である，と考えること も可能である。

断層破砕帯に関する研究では，横ずれ断層が 10 $\mathrm{km}$ 変位した場合でも,数十七ンチメートル程度の ガウジ (gouge) 帯しか形成されないことが知ら
れている（狩野・村田，1998）。しかし，ユニット $\mathrm{C}$ の厚さは約 $1 \mathrm{~m}$ もあり, ユニット $\mathrm{B} ・ \mathrm{D}$ からの 物質の取り込みによってだけではこの厚さは説明 できない。T8-till の形成過程の復元の際に, Phase 2 において, 上下ユニットからの物質の取 り込みに加えて, outwash flood-loam の変形を想 定したのは，このことを説明するためである。

(2) T9-till

T9-till の水河底変形地層は $\mathrm{B}^{\prime} \cdot \mathrm{C}^{\prime} \cdot \mathrm{D}^{\prime}$ の三つの ユニットに分けられた。T9-till は 1 回の氷河前進 に伴って形成されたと考えられ，その形成過程は 三つのフェーズに分けられる（図 7B）。

Phase 1 : 水河前面の地点 T9 には, 細粒物質に 富む基質支持の厚い支流性堆積物の上位に, オープンワークで砅支持の支流性堆積物が堆 積していた。

Phase 2: 支流性堆積物最上部層が氷河による 圧密と引きずりによって変形·変質し, ユニッ ト B'が形成された。さらに, 水河の引きずり が継続し，それに伴ってユニット $\mathrm{B}^{\prime}$ の基底付 近が強く変形してユニット $\mathrm{C}^{\prime} \cdot \mathrm{D}^{\prime}$ が形成され た。

Phase 3 : 水河の縮小過程に, 氷河表面や内部 起源の角閃岩の碟が堆積してユニット $\mathrm{A}^{\prime}$ が形 成された。

水河底変形が起きていた Phase 2 において，ユ ニット $\mathrm{B}^{\prime}$ の基底付近が強く歪んでユニット $\mathrm{C}^{\prime}$ が 形成されたと解釈したのは, 以下の理由による。1) ユニット B'からユニット C'にスムーズに連続す る破断面（図 6 の構造(2)'）が, 粘土化した部分を 伴っていること。2）ユニット $\mathrm{B}^{\prime} \cdot \mathrm{C}^{\prime}$ を構成する 角閃岩磁はユニット $\mathrm{C}^{\prime}$ の方が著しく細粒であるこ と。3）粘土サイズの物質を挟む破断面がユニット B'における歪の局所化で形成されたと解釈できる こと。いっぽうユニット D' は破断面 (図 6 の構造 (4)') の発達を伴うものの, 直下のユニット $\mathrm{E}^{\prime}$ (支 流性堆積物）と同じ層相を示す。したがって，ユ ニット $\mathrm{D}^{\prime}$ では破断は弱く，ユニット $\mathrm{B}^{\prime} \cdot \mathrm{C}^{\prime}$ の変 形に付随して生じたものと考えられる。

\section{3）ティルの変形様式と氷河流動への寄与}

氷河底変形地層の変形構造は, 水河の “底面す 
ベり”に伴う引きずりによって生じるので，その 歪は“底面すべり”と“氷河底地層変形”の程度 を反映する。またそれらは, 水河流動の性質を決 定づける重要な因子であることが知られている (例えば, Benn and Evans, 1998)。これらのこ とから, T8-till と T9-till の水河底変形地層の歪 から, かつての水河流動の性質を復元できる可能 性がある。しかし，ティルの歪ならびに氷河流動 への影響を評価する方法は検討の緒にもついてい ない。そこで本研究では, T8-till では剪断面角, T9-till では礫の破砕度を指標としてティル形成当 時の変形様式を推定し, 氷河流動の性質を検討す ることを試みた。

(1) T8-till

T8-till の歪の指標とした剪断面角とは, 脆性剪 断帯において最も連続のよいリーデル剪断面（R1 面）が剪断方向に対して斜交する角度のことであ り, その角度は, 同じ応力条件下では堆積物が延 性的な場合ほど大きくなり, 同じ堆積物の場合に は加えられる応力が強いほど増加する傾向がある (加藤・垣見, 1994)。また 30 度未満の剪断面角 は脆性的な変形を, それ以上の剪断面角は延性的 な変形を示唆すると考えられている。ティルに加 えられる応力は, ユニット内でほぼ一定と考えら れるので, 剪断面角は変形のし易さ（歪やすさ） の指標と見ることができる。

図 8A は, ユニット中の層相の細かな違いを考慮 して, T8-till の深さ方向の剪断面角の分布を復元 したものである。このティルについては，1回目 の氷河前進によって形成されたユニット $\mathrm{C} \cdot \mathrm{D}$ と, 2 回目の水河前進によるユニット B を分けて議論 する必要がある。ただし，ユニット C 最上部の角 閃岩の角砂と石英・長石の破砕岩片を挟む破断面 (図 4 の構造(3), 口絵 1-5) がほとんど乱されてい ないことから,ここでは, 2 回目の氷河前進に伴 うユニット Cの変形の程度は極めて小さいと考え，

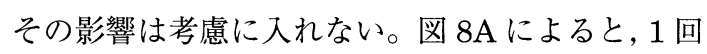
目の氷河前進による歪が非常に大きく，当時の ティルは延性的に変形したと考えられる。このこ とから, 1 回目に前進した氷河は, 地点 T8におい て“氷河底地層変形”を有効な流動メカニズムの

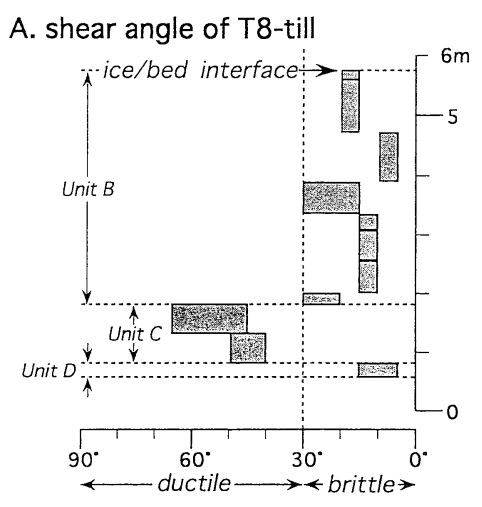

B. Degree of fracturing of T9-till

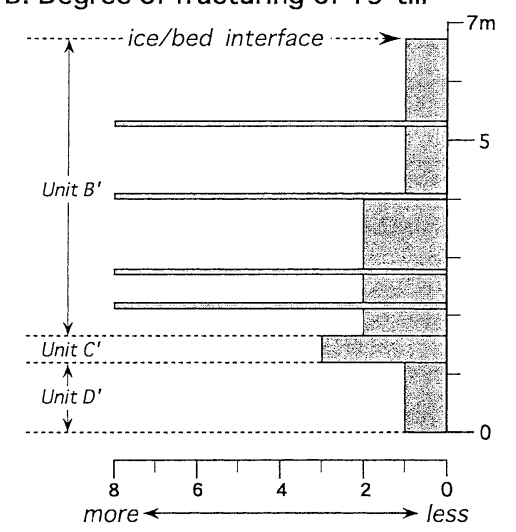

図 8 T8-till と T9-tillに打ける仮定的な歪の垂直 分布.

Fig. 8 Vertical patterns of hypothetical strain in subglacial deforming bed of T8-till and T9-till.

一つとしていたと考えられる。

いっぽうユニット B の歪は全体的に小さく, 脆 性的な変形を示唆している。II 章で述べたように， 水河底変形地層は氷河底面に近い部分ほど強い水 河性剪断応力を受けるので，その歪は概して上位 の層準ほど大きくなる。しかし，このユニットに 関してはその傾向が見られず，ユニットの下部ほ ど歪が大きくなっている。このような歪の垂直分 布から, 2 回目に前進した氷河は地点 $\mathrm{T} 8$ において ユニット B 全体を引きずっていたと考えられる。

(2) T9-till

このティルの剪断面角は不明暸で，T8-tillのよ うに系統的に計測するのは困難である。そこで T9- 
till については, 「1 度の水河前進で形成され, 原 岩物質の大部分が粗粒礫であった」ということを 踏まえ, 礫の破砕度を歪の大きさの指標とした。

ここでは, 初生的な構造を保ったまま剪断面が形 成されているものを破砕度 1 とし, 堆積物の破砕 が進行してその粒度が Wentworthの粒度区分に おいて1ランク小さくなれば破砕度が一つ大きく なるとする。

礫の破砕度に基づいて評価した T9-till の歪を 図 8B に示す。この図によると, ユニット B' 中の 粘土サイズの物質を挟む破断面 (図 6 の構造(2)', 口 絵 1-10・11）において極端に破砕度が高くなるも のの, 水河底変形地層全体 $\left(\right.$ ユニット $\left.\mathrm{B}^{\prime} \cdot \mathrm{C}^{\prime} \cdot \mathrm{D}^{\prime}\right)$ の破砕度は小さい。このことは氷河の流動に T9till の変形の寄与が大きくはなかったことを示唆 している。ここで注目すべき点は, ユニット $\mathrm{B}^{\prime} \cdot \mathrm{C}^{\prime}$ ・ D'において，下部ほど破砕度が高くなっている事 実である。ユニット $\mathrm{B}^{\prime}$ の最上部は水河底面と接し ていたので，底面すべりに伴う剪断応力を最も強 く受けたはずである。しかし，そこでは顕著な細 粒化は見られない。すなわち, T9-till 形成時の水 河は底面すべりは顕著ではなかったこと, 水河は 地点 $\mathrm{T} 9$ 付近において地層を面的に引きずり， ユ ニット $\mathrm{B}^{\prime} \cdot \mathrm{C}^{\prime} \cdot \mathrm{D}^{\prime}$ 全体をシート状に形成したこと を意味している。

\section{4）水河底熱的コンディション}

\section{(1) T8-till}

地点 $\mathrm{T} 8$ における 1 回目の水河前進時にユニッ ト C が延性的に変形された，という解釈に基づけ ば, その剪断強度は剪断応力に対してかなり小さ かったことになる。ユニット Cのような粘土サイ ズの細粒物質で構成される堆積物が延性的に変形 するためには，構成物質中に間隙水があり，その 水圧が静水圧よりも高い過剩間隙水圧となる必要 があることから, 当時の水河底面は融解点にあっ たと考えられる。

2 回目の氷河前進時にはユニット $\mathrm{B} / \mathrm{C}$ 境界です ベりが生じ，ユニット C はほとんど変形しなかっ たのに対し，ユニット $\mathrm{B}$ の基底部は強く歪んだ。 ユニット $\mathrm{B}$ は緻密で, 粗粒な礫だけからなり, 常 温状態では粘土サイズのユニット Cよりも摩擦強
度が大きいはずである。しかし, 変形の程度はユ ニット $\mathrm{C}$ よユニット $\mathrm{B}$ の摩擦強度の方が小さく, 2 回目の水河前進時には, ユニット $\mathrm{B} ・ \mathrm{C}$ の間で 摩擦強度が逆転していたことを示す。この現象は, 当時の水河底面が凍結状態にあり, 間隙水が凍結 することによってユニット C の摩擦強度がユニッ ト Bより大きくなっていたことを意味するのかも しれない。

(2) T9-till

T9-till の形成は，ユニット $\mathrm{B}^{\prime} ・ \mathrm{C}^{\prime}$ の起源物質 (粗粒角碟層) がユニット $\mathrm{D}^{\prime} \cdot \mathrm{E}^{\prime}$ の起源物質（砂 質シルトの基質支持碟層）との境界ですべること によって始まった。図 8B に示した歪に基づくと， その際の変形は粗粒角礫層であるユニット $\mathrm{B}^{\prime}$ の基 底付近に集中し, その結果, 細粒角砂層化したユ ニット $\mathrm{C}^{\prime}$ が生じた。この時に基質支持堆積物（ユ ニット $\left.\mathrm{E}^{\prime}\right)$ の最上部にまで変形が及び, ユニット D'が形成された。このユニット $\mathrm{D}^{\prime}$ の歪はユニッ ト $C^{\prime}$ に比べて極端に小さい。しかし常温での摩擦 強度は, 砂質シルトの基質支持層であるユニット $\mathrm{E}^{\prime}$ の方が, 粗粒角砂層であるユニット $\mathrm{B}^{\prime} よ り$ 小 さいはずである。すなわち, T9-till の形成時にも, T8-till と同様に摩擦強度の逆転が起こっていた。 したがって, T9-till を形成した氷河も底面凍結状 態にあった可能性がある。

\section{VI. まとめと今後の課題}

本研究では, 日高山脈トッタベッ谷の 2 地点に 露出する氷河堆積物（T8-till と T9-till）について 層相・堆積構造を記載し，1）T8-till と T9-till が それぞれ 2 回と 1 回の水河前進・後退に伴って形 成されたこと，2）再ティルの水河底変形地層に垂 直・水平方向への圧密・引きずりで形成された剪 断面, 褶曲, 断層粘土など多様な変形構造が発達 することを明らかにした。さらに，3）リーデル剪 断面と破砕度を指標とした氷河底変形地層の歪復 元を試み, T8-till は底面が融解していた氷河に よって形成・変形され, 後に再前進した底面凍結 氷河によってさらに変形されたこと,また, T9-till は底面が凍結していた氷河によって形成・変形さ れた可能性を指摘した。 
剪断面角に基づく歪の解釈は本研究による新し い試みであり, 水河堆積物への適用の妥当性や定 量的な評価などのいくつかの問題点が残されてお り, 今後さらに詳しい検討を要する。例えば, 微 細構造観察（例えば, van der Meer, 1996; van der Wateren, 1999) や力学実験(例えば, Iverson et al., 1998; Müller and Schlüchter, 2001) など の手法や成果を取り入れることによって歪を定量 的に評価できれば, 氷河の流動速度の議論に発展 させることができるだろう。氷河底における熱的 条件の復元は, 古気候を復元するためにも重要で あり, 本稿で試みた氷河底変形地層に基づく氷河 地質学的・氷河学的な検討は重要な意味を持つも のと考える。

\section{謝 辞}

本研究を行うにあたり, 東京都立大学の岩田修二教授, 明治大学の長谷川裕彦博士をはじめとする寒冷地形談話 会, 水河作用研究グループの諸氏に有益な御助言を頂い た。記して厚くお礼申し上げます。本研究には, 文部科 学省研究補助金（課題番号 08680182, 10680095：いず れも研究代表 平川一臣; 課題番号 13680098 , 研究代 表 渡邊悌二) を使用した。

\section{文献}

Alley, R.B., Blankenship, D.D., Bentley, C.R. and Rooney, S.T. (1986): Deformation of till beneath Ice Stream B, West Antarctica. Nature, 322, 57 59.

Benn, D.I. (1994): Fluted moraine formation and till genesis below a temperate glacier: Slettmarkbreen, Jotunheimen, Norway. Sedimentology, 41, 279-292.

Benn, D.I. and Evans, D.J.A. (1998): Glaciers and Glaciation. Arnold.

Blankenship D.D., Bentley, C.R., Rooney, S.T. and Alley, R.B. (1986): Seismic measurements reveal a saturated porous layer beneath an active Antarctic ice stream. Nature, 322, 54-57.

Boulton, G.S. (1986): A paradigm shift in glaciology? Nature, 322, 18.

Boulton, G.S., van der Meer, J.J.M., Hart, J.K., Beets, D., Ruegg, G.H.J., van der Wateren, F.M., Jarvis, J. (1996): Till and moraine emplacement in a deforming bed surge-an example from a marine environment. Quatern. Sci. Rev., 15, $961^{-}$
987.

Dreimanis, A. (1989): Tills: Their genetic terminology and classification. In Goldthwait, R.P. and Matsch, C.L. eds. : Genetic Classification of Glacigenic Deposits. Balkema, 1117-1184.

Dreimanis, A. (1993): Small to medium-size glcitectonic structures in till and in its substratum and their comparision with mass movement structures. Quatern. Intern., 18, 69-79.

Hart, J.K. (1995): Subglacial erosion, deposition and deformation associated with deformable beds. Progr. Phys. Geogr., 19, 173-191.

Hart, J.K. (1998): The deforming bed/debris-rich basal ice continuum and its implications for the formation of glacial landforms (flutes) and sediments (melt-out till). Quatern. Sci. Rev., 17, 737754.

Hart, J.K. and Boulton, G.S. (1991): The interrelation of glaciotectonic and glaciodepositional processes within the glacial environment. Quatern. Sci. Rev., 10, 335-350.

Iverson, N.R., Hooyer, T.S. and Baker, R.W. (1998): Ring-shear studies of till deformation: Coulombplastic behavior and distributed strain in glacier beds. J. Glaciol., 44, 634-642.

岩崎正吾・平川一臣・澤柿教伸 (2000a): 日高山脈卜ッ タベッ川源流域における第四紀後期の水河作用とその 編年. 地理学評論, $73 \mathrm{~A}, 498-522$.

岩崎正吾・平川一臣・澤柿教伸 $(2000 \mathrm{~b})$ ：日高山脈工开 オマントッタベッ川流域における第四紀後期の水河作 用とその編年. 地学雑誌, 109, 37-55.

狩野謙一 一村田明広 (1998): 構造地質学. 朝含書店.

加藤俊弘 - 垣見碵一 (1994): 地質構造の解析一理論と 実際一. 愛智出版.

van der Meer, J.J.M. (1996): Micromorphology. In Menzies, J. ed. : Glacial Environments: Processes, Sediments and Landforms. Butterworth-Heinemann, 335-355.

Müller, B.U. and Schlüchter, C. (2001): Influence of the glacier bed lithology on the formation of a subglacial till sequence - Ring-shear experiments as a tool for the classification of subglacial tills. Quatern. Sci. Rev., 20, 1113-1125.

小野有五・平川一臣 (1975): ヴュルム氷期における日 高山脈周辺の地形形成環境. 地理学評論, 48, 1-26.

Ruszczynska-Szenajch, H. (2001): "Lodgement till" and "deformation till". Quatern. Sci. Rev., 20, 579581.

van der Wateren, F.M. (1999): Structural geology and sedimentology of the Heiligenhafen till section, Northern Germany. Quatern. Sci. Rev., 18, 1625-1639.

(2002 年 4 月 29 日受付, 2002 年 6 月 17 日受理) 